\title{
THE APOLITICAL SOCIAL CONTRACT: CONTEMPORARY DEMOCRATIC POLITICS BEYOND DEPOLITICIZED SOCIAL CONTRACT
}

\author{
Leno Danner* \\ leno_danner@yahoo.com.br
}

RESUMO Critico no artigo, a partir da análise da posição original de Rawls e da ideia de sociedade complexa de Habermas, o ponto de partida não político das teorias do contrato social, argumentando que este mesmo ponto de partida despolitizado leva - no momento em que apaga e mesmo elimina, com o objetivo de alcançar o acordo político, as lutas sociais entre classes, o status quo e as diferenças sociopolíticas entre os grupos sociais como a base da configuração institucional e societal - à recusa da centralidade das lutas sociais entre classes como a base de dinamização da evolução social e da constituição institucional. Ele leva, além disso, ao institucionalismo forte, isto é, à centralidade das esferas e dos sujeitos formais (instituições, seu procedimentalismo e elites, como partidos politicos e cortes) em relação às esferas e sujeitos informais (sociedade civil, movimentos sociais e iniciativas cidadãs). Portanto, as consequências políticas de um ponto de partida não político ou despolitizado são triplas: (a) a despolitização das lutas sociais entre classes sociais opostas; (b) o institucionalismo forte por meio da ênfase em instituições políticas e no Estado democrático de direito despolitizados; $e$ (c) o enfraquecimento de uma práxis política radical que é realizada por movimentos sociais e iniciativas cidadãs a partir de uma contraposição direta e mesmo de uma substituição das instituições, de seu procedimentalismo e elites pela práxis político-cultural espontânea dos movimentos sociais e das iniciativas cidadãs. O grande problema e o grande desafio das sociedades

* Universidade Federal de Rondônia. Artigo recebido em 04/03/2016 e aprovado em 08/08/2016.

KRITERION, Belo Horizonte, nº 136, Abr./2017, p. 101-123 
democráticas contemporâneas, ou seja, a correlação entre institucionalismo forte, partidos políticos e oligarquias econômicas, não podem ser resolvidos por meio da ênfase, por parte do paradigma jurídico-político procedimentalista, no institucionalismo e no Estado Democrático de Direito, senão que apenas por meio de uma reafirmação da práxis política como o verdadeiro núcleo da constituição, legitimação e evolução institucional e societal, o que implica que a política democrática seja concebida como luta permanente em relação ao institucionalismo forte por parte dos sujeitos politicos advenientes da sociedade civil, exigindo-se, aqui, uma politização permanente e radical das esferas públicas e dos sujeitos informais.

Palavras-chave Procedimentalismo, Contrato Social, Política Democrática, Institucionalismo Forte, Radicalismo Democrático.

ABSTRACT This article provides a criticism of the apolitical starting point of social contract theories through the analysis of Rawls's original position and Habermas's idea of complex society, arguing that such depoliticized starting point leads to the refusal of the centrality of social struggles between classes as the basis of streamlining social evolution and institutional constitution. In order to achieve political agreement, it erases and even eliminates the struggles between social classes, the status quo and the social-political differences between social groups as the core of societal and institutional configuration. Moreover, it leads to strong institutionalism-the centrality of the formal spheres and subjects (institutions, their proceduralism and legal staff, as political parties and courts) in relation to informal spheres and subjects (civil society, social movements and citizen initiatives). Therefore, the political consequences of a depoliticized or apolitical starting point are threefold: (a) the depoliticization of social struggles between opposed social classes, (b) the strong institutionalism by the emphasis in the depoliticized institutions and in the rule of law, and (c) the weakening of a democratic political praxis performed by social movements and citizen initiatives from a direct contraposition and even substitution of the institutions, their proceduralism and legal staff with the spontaneous politicalcultural praxis of these social movements and citizen initiatives. The great problem and challenge of contemporary democratic societies, namely the correlation between strong institutionalism, political parties and economic oligarchies, cannot be resolved from the juridical-political procedural paradigm's emphasis on institutionalism and the rule of law, but only by a reaffirmation of political praxis as the fundamental core of institutional and societal constitution, legitimation and evolution, which implies that democratic politics must be 
conceived of as a permanent struggle against strong institutionalism by the political subjects of civil society. Here a permanent and radical politicization of the informal public spheres and subjects is required.

Keywords Proceduralism, Social Contract, Democratic Politics, Strong Institutionalism, Democratic Radicalism.

\section{Introduction}

Contemporary political philosophy uses and stylizes the notion of social contract as a methodological procedure for the foundation of an objective conception of social normativity which has an eminently political sense and goal: to serve as an epistemological-moral basis to the mediation of opposed social vindications, social struggles, political-cultural subjects and institutional dynamics. However, despite their intention to ground a political theory for a contemporary pluralistic democratic society, nothing is more apolitical than the starting point of social contract theories: their impartiality, neutrality and formalism regarding historical-sociological class struggles, status quo and empirical political conditions leading to a historical-sociological blindness in relation to the political theory, political subjects and also the social-political consequences of political praxis. Indeed, Rawls's original position and Habermas's idea of complex society as the basis of their juridical-political procedural paradigm erase the fact that political praxis is from the beginning a very political struggle, a very profound conflict between social classes. So an apolitical normative starting point obliterates such social-political contrapositions and conflicts, as it erases the class contraposition and division, leading as a consequence to a hypothetical consensus which not only presents a historicalsociological blindness by denying the social struggles between opposed social classes as the starting point of a political theory, but also leads to a kind of strong institutionalism which centralizes both the institutional and societal constitution, legitimation and evolution within juridical-political institutions, their impersonal proceduralism and legal staff, minimizing and even eliminating the political role of social movements and citizen initiatives. Here, formal spheres and subjects have the central role and priority regarding informal spheres and subjects, so that institutions, their proceduralism and legal staff become more important than civil society, its spontaneous political praxis and social movements.

In other words, an apolitical theoretical starting point implies three great problems to the social contract theories and, as a consequence, to a radical 
democratic political praxis based on the social contract: (a) the effacement of the political struggles between opposed social classes, the effacement of the social-political-cultural differences and status quo as the theoretical-political basis from which we can start; (b) the strong institutionalism, which minimizes the political-normative importance of civil society, in the sense that the rule of law and the juridical-political institutions become the basis and the central subject of institutional constitution, legitimation and evolution, as well as of the definition of society, that is, the formal spheres and subjects (parliaments, courts, political parties) become more important politically than informal spheres and subjects (civil society, social movements and citizen initiatives); (c) juridicalpolitical institutions, their internal proceduralism and legal staff centralize and monopolize the constitution, the legitimation and the social boosting of social normativity, then, social movements and citizen initiatives can only influence institutions from the outside and in an indirect way, because the institutional formal spheres and subjects are the central basis and subjects of institutional and societal constitution, legitimation and evolution. The central argument of this article is that a political theory for a contemporary society cannot base its normative content, diagnoses and political orientations in a depoliticized starting point which erases the political struggles between social classes as the effective fundament of social evolution and institutional constitution, as it cannot lead to the centrality of juridical-political institutions - the rule of law-as the basis of the institutional and societal legitimation and evolution, beyond social movements and citizen initiatives. So, according to the view adopted here, it is the civil society and its social movements and citizen initiatives that can provide the basic political sphere and subjects of social evolution and institutional constitution: it is from here that a political theory can overcome its historical-sociological blindness, its apolitical starting point which leads, directly or indirectly, to strong institutionalism. The praxis is once more the basis of politics, and not institutionalism, the rule of law and their internal proceduralism and legal staff.

\section{Rawls's and Habermas's Juridical-Political Procedural Paradigm: A Recovery of the Social Contract in Contemporary Political Philosophy}

John Rawls's A Theory of Justice (and after his justice as fairness as a whole) and Jürgen Habermas's Between Facts and Norms (and also his procedural juridical-political paradigm as a whole) are based on a renewal and on a recovery of the social contract theory as starting point to think about and ground contemporary social life and, to my case here, the juridical-political 
institutions (see Rawls, 2000a, 2000b; Habermas, 2002b, 2003a). According to them, this is an exigency of the current pluralistic or post-metaphysical times, and that means an important theoretical change regarding the way and the sense of the normative foundation: ethical-political theory must assume a procedural, impartial and neutral standpoint in order to achieve a form of social normativity which can ground and streamline both social life and juridicalpolitical institutions. Philosophical theory cannot impose from the beginning and vertically, from top to bottom - it has no legitimacy for such-, a normative content that common people should draw upon in their lives nowadays, in social interactions with the goal of reaching a minimal agreement about what is desired in terms of ethical-political principles and socially binding behaviors, including those concerning the way and the form of juridical-political institutions, their programming and functioning over time. This kind of social normativity cannot be based on an essentialist or naturalized foundation which violates the irreducibility of differences, which is one of the most important and fundamental achievements of these pluralistic or post-metaphysical times. Again, the notion of social normativity from now on is the result of the social contract established between equal and free citizens who take their differences serious as something that must be protected and fomented both by the ethical-political content accorded in the social contract and by juridical-political institutions defined by that ethical-political content resulted from the social contract's procedure. Likewise, the irreducibility of differences must guide and define the very type of the procedural way of discussion and decision in order to establish the initial - fair, impartial and neutral, impersonal, or at least equal-conditions of discourse, participation and final agreement (see Rawls, 2000b, 2002, 2003; Habermas, 1989, 1990, 2002b).

The basic intuition of Rawls and Habermas is very clear and seductive, especially for modernity's sons, for liberalism's land: a procedural, impartial, impersonal and neutral social contract characterized by a decentered consciousness means a non-egocentric and non-ethnocentric attitude by each of the participants of the social contract's dialogue-praxis, which leads to an overlapping consensus (Rawls) or to a universalistic epistemological-moral paradigm (Habermas) that is socially binding (see Rawls, 2000b, 2002, 2003; Habermas, 2012a, 2003a, 2002b, 1989). In other words, from one same theoretical-political starting point, in which people do not know what they are and what they have in the moment of the social contract nor what they will be and have in the future society resulting from this contract (Rawlsian original position), they will think and act in a non-egocentric and non-ethnocentric way, putting themselves in the place of others and deciding in favor of absolute respect for individual rights 
and for the irreducibility of differences, as much as to the legitimation of social rights as a basic institutional political program (see Rawls, 2000a, 2000b, 2002, 2003). The same happens in the Habermasian discourse circle which is based on the normative reconstruction of European cultural modernity: people can only achieve a binding social agreement by renouncing to impose their particular worldviews on others and by adopting a formalist and impartial justification of the notion of social normativity, which requires, as said above, an impartial, formal and neutral argumentation which must adopt a non-egocentric and non-ethnocentric attitude and role by putting oneself in the place of others (see Habermas, 2012a, 2012b, 2002a, 2002b, 1989, 1990). Only through that procedure can the epistemological-moral universalism be performed and reached, that is, social normativity is grounded on and generated by a non-egocentric and non-ethnocentric personal and group attitude in the discourse circle that minimizes the importance of political, social and cultural rooting and divisions (see Forst, 2010; Honneth, 2003).

Attention should be paid to the conditions of the social contract for the juridical-political foundation and the social agreement in democratic societies. In considering both Rawls's and Habermas's theoretical-political starting point, respectively the Western liberal democratic societies' history and public culture and the European cultural modernity's universalist self-comprehension, it can be perceived that philosophical theory has a justification to choose the procedural paradigm and its basic characteristics (formality, impartiality, impersonality and neutrality) as the grounding basis for social normativity and for the constitution and dynamics of the social contract. Indeed, both Western liberal democratic societies' history and public culture and European cultural modernity's universalist self-comprehension supply the idea that an essentialist and naturalized foundation cannot organize, frame and orientate all individuals and social-cultural groups in a democratic society, in a post-metaphysical era, because each individual and social-cultural group have particularized worldviews which are incompatible and competing with each other. So the social-political-epistemological imposition of an essentialist and naturalized foundation on all individuals and social-cultural groups, as the basis of society's constitution, legitimation and evolution, not only delegitimizes pluralism, public dialogue and cooperation between different persons and groups; it also leads, as a consequence, to mutual conflict and authoritarian imposition of one creed on others, denying pluralism as a fact of the Western democratic societiesand even of globalization - and, therefore, as the theoretical-political starting point where the normative paradigm takes place and starts (see Rawls, 2000b, p. XI; 2002, p. 24; 2003, § 01, p. 06; Habermas, 2012a, pp. 384-385; 2012b, 
p. 87). Of course, this implies the weakening of the epistemological-moral paradigms in the sense that they cannot be based on a strong objectivity in the style of the metaphysical-theological foundations which are grounded on an essentialist and naturalized understanding and praxis. From now on, in a pluralist and democratic world, characterized by individualism in lifestyles, religious-cultural pluralism and skepticism regarding universalist foundations, only a moderate, neutral, impartial and inclusive procedure of epistemologicalpolitical grounding is appropriate to guarantee the validity of the norms and practices in these pluralist, post-metaphysical times - and this also implies and means a non-egocentric and non-ethnocentric vital consciousness as the heritage and legacy of democracy and modernity (see Rawls, 2000b, pp. 56-57, p. 321; 2002, p. 257; 2003, § 06, p. 22; Habermas, 1989, pp. 61-141; 1990, pp. 11-17; Honneth, 2003, p. 280; Forst, 2010, pp. 26-27, p. 46).

According to Rawls, this is the most precious normative teaching that modern religion wars have allowed and bequeathed to us, sons of modernity and liberalism, after the constitution and evolution of democratic societies: pluralism as an irreversible and very positive development, the radical irreducibility of differences. And here, by the assumption of the democratic cultural and institutional history, the philosophical theory can sustain itself on its pretention of constructing a procedural paradigm which is at the same time neutral, impersonal, impartial and formalist regarding ways of life by refusing an essentialist and naturalized foundation, by the affirmation of a political theory to a democratic political society (see Rawls, 2002, pp. 32-33, p. 50). According to Habermas, the theory of modernity discovers that European cultural modernity is characterized by the separation between nature or objective world, culture or society and individuality as the fundamental theoretical-political basis to the constitution and grounding of the modern societies. Unlike traditional societies, which are marked by the strong imbrication among nature, society and individuality, which naturalizes social constitution and evolution, as much as it does not allow the emergence of a notion of individuality that is separated from nature and society, the European cultural modernity is highly reflexive because of that separation. So, traditional societies are not reflexive or rational, as they do not enable social mobility and a rational way of life (everything is naturalized and the individual has no self-consciousness of the society's historical and political constitution, grounding and evolution). On the other hand, European cultural modernity historicizes and politicizes social constitution by denaturalizing the constitution, legitimation and evolution of society, by fomenting a notion of individuality that becomes the theoretical-political basis of the epistemologicalmoral foundation (see Habermas, 2012a, pp. 140-142; 2002b, pp. 07-08, p. 22; 
2002a, p. 74; 2003b, p. 38; 1997, p. 13). Now, how is the epistemological-moral foundation possible and performed in European cultural modernity?

The historicization and politicization of society, allied to the constitution of an autonomous notion of self-reflexive individuality, lead to the fact that modernity's normative paradigm is constructed from the necessity of a social interaction between individuals and groups that cannot be based on an essentialist and naturalized foundation, which must be characterized by a rational dialogue and cooperation based on formal, impartial, impersonal and neutral arguments, principles and practices in a procedural way-Habermas's concept of linguistification of the sacred refers to this specificity of European cultural modernity in relation to traditional societies (see Habermas, 2012a, p. $139 ; 2012$ b, p. 196). This leads the European man (as an idealized model) to reach a non-egocentric and non-ethnocentric consciousness, as it leads European culture to become a decentered and then universalist way of life and form of societal organization that enables communicative ethics from the centrality of differences and of pluralism (Piaget's and Kohlberg's post-conventional moral stage, used by both Rawls and Habermas) (see Habermas, 2012a, pp. 142-148; 2012b, p. 263; 1989, pp. 143-164; Rawls, 2000a, § 75, pp. 544-551; 2002, pp. $132-133 ; 2003, \S 59$, pp. 278-282). This is the normative paradigm of modernity's rational universalism characterized by proceduralism, impartiality, neutrality and formalism as the basic platform to the epistemological-moral foundation in a post-metaphysical era. Here, the conditions for a social contract become clearer: only from a procedural way of foundation that is impartial, neutral and formal regarding ethical-political contents and, more importantly, concerning social-political subjects, roots and status quo it is possible to ground an objective notion of social normativity which can serve as epistemological-moral paradigm to orientate and frame social vindications and interactions, institutional dynamics and the correlation between system and lifeworld. Contemporary conditions of individualism, pluralism and skepticism regarding metaphysical-theological foundations only admit such a procedural, neutral, impartial and formal paradigm in terms of normative grounding. As will be argued, Rawls and Habermas wrongly require an apolitical starting point which erases the social-political differences, status quo and class contrapositions in order to seriously consider the social-political-cultural differences, status quo and class oppositions after this procedural, impartial, impersonal, neutral and formal normative beginning!

It is important now to focus on the social contract's context for the juridicalpolitical foundation. This context can be understood through Habermas's use of the concept of complex society as the basic characteristic of a contemporary democratic society (see Habermas, 2003a, 2003b, 1997). Habermas posits that 
contemporary societies can no longer be understood as a totality streamlined and defined by conflicting and opposed social classes. Indeed, contemporary societies have two important features which differentiate them in relation to both traditional societies and the modern industrial society, namely that contemporary societies are divided into (a) irreconcilable and very particularized individuals and social-cultural groups as in (b) competing, self-referential and self-subsisting social systems or institutions that have a technical-logical programming and functioning, a non-political and non-normative constitution, legitimation and evolution opposed to the lifeworld's normative constitution, legitimation and evolution (see Habermas, 2003a, pp. 17-18). Against liberalism (and particularly against conservative liberalism — see Hayek, 1987, 1995; Nozick, 1991) that denies the objective character of social systems and institutions, which determines status quo; yet against liberalism's individualization of society (society does not exist as a structural totality, as a self-conscious and programmable totality, as Hayek said), Habermas emphasizes that the social systems or institutions (as capitalist market and bureaucratic-administrative State) determine social evolution and the definition of the status quo, which requires an interventionist and compensatory institutional action - which is in line with Rawls's concept of basic structure of the society as alternative to the conservative liberalism of Hayek and Nozick (Habermas, 2003a, pp. 17-18, p. 119; Rawls, 2000a, § 02, p. 08, § 41, p. 286; 2000b, p. 03, p. 203; 2002, p. 309; 2003, § 04, pp. 13-14, § 12, p. 56). Against the socialist idea that society is a totality streamlined and defined by conflicting social classes, Habermas argues that a contemporary complex society is divided into many self-referential, self-subsisting and autonomous social systems or institutions, as much as it is constituted by individuals and social-cultural groups with no class belonging and consciousness- then the political action in a complex society is always a short range praxis which has no macro social-political effects and subjects, as it cannot modify all social spheres that are defined by each social system's constitution and movement (see Habermas, 2012a, p. 588, p. 685; 2012b, p. 278, p. 365; 2003a, p. 61, pp. 331-333; 1997, p. 163).

Therefore, a contemporary complex society acquires from here a very particular constitution which leads to the need of a procedural, impartial, neutral and formal juridical-political paradigm that places institutions as the basic core and subject of social evolution beyond social classes and their struggles for hegemony, beyond - if social class and class struggles are very problematic concepts - social movements and citizen initiatives. Here, a radical and direct political praxis by social movements and citizen initiatives is denied and substituted with institutionalism and its internal impartial, impersonal, neutral 
and formal procedures and legal actors as the only way, practice and subjects of institutional legitimation and social evolution (see Habermas, 2003a, pp. 20$25 ; 2003$ b, p. 21, p. 72). A complex society, let it be remembered, is constituted by much particularized individuals and social groups and by many different, closed and conflicting social systems or institutions. As a consequence, a complex society has not, firstly, a political-material center from which the societal dynamics as a whole could be defined, programmed and streamlined: social dynamics is a summation of individualized actions with a non-messianic consciousness of totality, as it is streamlined by the self-referential movements of each social system. Secondly, it implies the fact that society is divided, as said above, into many particular spheres and social-cultural subjects, losing its totalizing characteristic: here, society is no longer a totality which has an intrinsic imbrication, dependence and dynamicity concerning its parts, which are always individualized, particularized, becoming self-referential, self-subsisting and autonomous regarding the social context from where they emerge. So if society is no longer a totality, social-political actions are basically micro-actions with no structural impact and influence, as political institutional reformism reaches only specific social spheres in a short range. Thirdly, in a complex society there are neither social classes as macro social-political subjects nor class division and conflict, but only individuals and social-cultural groups with no class belonging and consciousness, becoming particularized. A social-political praxis based on the centrality of a specific social class which carries and imposes universalizable interests in the name of all society does not exist anymore; it is no longer possible, in contemporary complex societies. Thus, democratic constitution, legitimation and evolution become a kind of institutional procedure which is impartial, impersonal, neutral and formal concerning the particularized individuals and social-cultural groups (see Habermas, 2003b, pp. 21-25, p. 72).

Here, a very important characteristic of complex societies appears as defining the sense and the way of Rawls's and Habermas's procedural juridical-political paradigm: the idea that juridical-political institutions, in the moment that macro social-political classes no longer exist, centralize the constitution, the legitimation and the foment of social normativity in the name of all society and beyond social movements and citizen initiatives (see Habermas, 2003a, pp. 24-25; 2003b, pp. 23-25, p. 72; 2012b, pp. 316-325; Rawls, 2000a, § 10, pp. 57-64, § 79, pp. $579-589 ; 2003, \S 44$, pp. 205-210, §54, pp. 257-262). Indeed, since there are no macro social classes which can ground and foment universalizable interests (as the working class in the Marxist theory), social normativity is not centralized and streamlined by a specific social class. Actually, social normativity is not centralized and streamlined by any individual or social class (although they can 
act based on it). It is here that the rule of law and, therefore, institutionalism acquires centrality in Rawls's and Habermas's juridical-political procedural paradigm as a renewal of the social contract theory. As a result of the Western democratic evolution, the rule of law and the juridical-political institutions (parliaments and courts, political parties and constitutional courts) as a whole become the basis from which social normativity is streamlined, legitimized and fomented to and in the name of the whole of society. Rawls and Habermas argue that contemporary democratic politics is organized from such interaction between institutions, their internal impartial, neutral and formal procedure, their internal legal staff, which constitute the formal spheres, rules and subjects and the social movements and citizen initiatives from civil society which constitute the informal spheres and subjects. From that dialectics, the institutions evolve and acquire form, as social movements and citizen initiatives can problematize social impasses and institutional deficits, as they can make social claims and political vindications to institutions and their legal staff (see Habermas, 2003a, p. 20, pp. 24-25, p. 83; 2003b, pp. 104-106).

A very important consequence of the centrality of the rule of law and of the juridical-political institutions is the fact that the rule of law is put as the normative center of society, the basis from which any social subject and social claim can be grounded in order to acquire political legitimacy to be discussed and socially imposed (see Habermas, 2003a, pp. 24-25, pp. 52-53). The rule of law and the juridical-political institutions appear here as non-political structures, that is, they are a procedural instance characterized by neutrality, impartiality, impersonality and formality regarding social-political forces and projects of social development (see Habermas, 2003a, p. 34, p. 53). That is the reason why they centralize, legitimize, streamline and impose a notion of social normativity in the name of all society, becoming not only the arena, the instrument and the steps from which social evolution is determined and legitimized, but also the effective subjects of such transformation. The rule of law and the juridicalpolitical institutions, in the moment that they are superimposed on the status $q u o$, social forces and political clashes, become neutral, impartial and formal regarding these dimensions, and, therefore, acquire the ability to centralize and guard social normativity, which is no longer a result of social struggles between opposed social subjects, between conflicting social classes, but a result of the internal procedure of the juridical-political institutions and their legal staff. Here, social movements and citizen initiatives cannot replace the juridical-political institutions both as keepers of social normativity and as effective political subjects of social transformation. Formal spheres and subjects constituted by juridical-political institutions and their legal staff have priority concerning the 
informal and spontaneous spheres constituted by social movements and citizen initiatives (see Habermas, 2003a, p. 82; 2003b, p. 105). As claimed by Rawls, violent civil disobedience is forbidden and illegal, because it hinders or at least minimizes the normative centrality of the juridical-political institutions in terms of democratic constitution and legitimation (democracy is defined by institutions' internal procedures and legal actors - social movements' and citizen initiatives' vindications and struggles acquire sense from here) (see Rawls, 2000a, §55, pp. 402-407, §57, pp. 411-418, §59, pp. 423-434). Likewise, Habermas posits that social movements and citizen initiatives can sensitize from the outside juridical-political institutions and their legal staff, but never replace them as the core and the political subjects of institutional legitimation and of social evolution (see Habermas, 2003b, pp. 105-106). Politics is institutional politics, political subjects are the institutions'formal subjects, the political arena and instruments are the institution's procedural way and rules: that is the result of the juridical-political procedural paradigm as the reconstruction of the social contract theory in a pluralist and post-metaphysical world, in a contemporary democratic complex society.

What is the reason for that? It is only possible to conceive of and build a radical democracy in a contemporary complex society if three important characteristics are seriously considered: the individualization of social subjects; the division of society into different, closed and competing social systems; and the systemic institutional self-referentiality (see Habermas, 2003a, pp. 17-18; 2003b, pp. 105-106; 2012a, pp. 267-268; 2012b, pp. 216-217; 1997, pp. 163164). These three conditions do not allow a direct political praxis by a macro social-political subject who can at the same time assume a notion of social normativity in the name of all society and challenge the centrality of juridicalpolitical institutions. These three conditions lead to the fact that each institution centralizes and monopolizes its specific field, so its internal procedures, practices and legal staff are the basic arena, instruments and subjects of institutional constitution, legitimation and evolution; likewise, due to the fact that each social system is self-referential, self-subsisting and autonomous regarding the lifeworld and civil society as a whole, only indirect interventions can minimize the pathologies of social systems, as spontaneous social movements and citizen initiatives can sensitize the self-structuration of juridical-political institutions and social systems from outside, but they can never replace the institutions' self-referentiality and internal procedure, instruments and legal actors (see Habermas, 2003b, pp. 105-106, pp. 147-148; 1997, pp. 143-144). That is the limit and the possibility of a democratic society. 
Now, it is exactly this apolitical starting point of the juridical-political procedural paradigm, based correlatively on post-metaphysical presuppositions and mainly on the idea of complex society, which determines a construction, by Rawls and Habermas, of a juridical-political paradigm that erases the political constitution of society and institutions as the fundamental normative starting point from which we must think and act in terms of democratic political praxis. Such apolitical starting point not only equalizes all social-political subjects (despite their differences), erasing their contrapositions and class belonging, but also eliminates the political centrality of social movements and citizen initiatives, of political clashes as the basic core, arena and subject of institutional constitution, legitimation and evolution. So, the juridical-political institutions (formal arenas, procedures, practices and subjects) become central in terms of the constitution, legitimation and evolution of democratic society, centralizing and monopolizing the grounding and the performance of social evolution beyond social movements and citizen initiatives (informal arenas, practices and subjects). The apolitical beginning does not allow a radical politics which can challenge systemic pathologies and political-cultural conservatism, because it leads directly (in conservative liberalism's view) and indirectly (in the theories of Rawls and Habermas) to strong institutionalism, centralizing and monopolizing institutional constitution, legitimation and evolution within the very institutions, which become closed regarding civil society's political movements and normative specificities and claims. That is my central criticism against Rawls's and Habermas's juridical-political procedural paradigm.

\section{The Fundamental Problems of Social Contract Theories: A Theoretical- Political Proposal}

A double problem can be perceived in the juridical-political proceduralism, namely its apolitical starting point, which erases the social-political-cultural differences as the basis of the institutional and societal dynamic and definition, and, as a consequence, its apolitical and institutionalist understanding of the juridical-political institutions in particular and of the social systems in general, which leads to a social evolution and legitimation that are centralized and defined basically by a kind of strong institutionalism. I argued above that a very interesting and problematic point of a juridical-political procedural paradigm is the fact that it intends to ground an objective notion of social normativity in order to organize the differences and resolve social-political problems by assuming an impartial, impersonal, neutral and formal way of foundation which erases these differences (see Habermas, 2003a, p. 87). In other words, an apolitical 
starting point is the theoretical option to face social-political problems, to frame and orientate social-political subjects and matters; an apolitical starting point, subject and procedure are the core and the instrument to solve social-political problems, to orientate social-political-cultural groups. Indeed, to both Rawls and Habermas, the initial conditions and characteristics of the social contract are exactly the impartial and neutral subjects, conditions and procedures of discourse, representation and foundation, or the necessity of a non-egocentric and non-ethnocentric moral consciousness as the basis of fair and universal agreement, because if we start from the social-political-cultural differences, we cannot achieve an impartial and neutral notion of social normativity. Contrarily to that, if we start from the lack of knowledge regarding our class-cultural belonging and status quo, we will decide in favor of an impartial and neutral notion of social normativity which is equal to all and which can be accepted by all (Rawls' original position). Likewise, if we start from the fact that we must justify our arguments and proposals in the discourse circle to all differences, we will perceive that only a rationalized non-egocentric and non-ethnocentric attitude can lead to an agreement concerning the public notion of social normativity. In the first place, therefore, the conditions and subjects of the social contract are very apolitical and they require an apolitical starting point, as if the social agreement could only be obtained from the depoliticization of both social subjects and social conditions.

The depoliticization of the social-political groups and conditions is more acute and problematic in the notion of complex society, which is, from the beginning, a form of limitation of the political praxis by the fact that contemporary democratic societies are no longer an interdependent totality or macro socialcultural structure, nor divided into macro social subjects or classes. By this concept, Habermas (and even Rawls) refuses the existence of macro social subjects who have the conditions to engage in a direct political praxis and a broad social change, since he denies that the social dynamics and institutional constitution are defined outside of the institutions, by social struggles between opposed social classes. The social groups are always individualized, particularized in terms of political-cultural belonging, so they cannot centralize and streamline a notion of social normativity or a wide political praxis in the name of all society. Likewise, institutions are the basis of their constitution and of social evolution-within them and through them the effective democratic political praxis actually takes place (see Habermas, 2003a, pp. 17-20; 2003b, pp. 104-105). The individuals and social-cultural groups can, of course, make normative claims and act politically in relation to juridical-political institutions, but never in the name of all society, substituting institutions, their formal procedures and legal 
staff, as other social-cultural groups as political subjects. Each social group and individual has very particularized worldviews that cannot represent or subsume all social worldviews and even society as a whole. A complex society has no political center from which all social dynamics and movements can be defined at once, by a nuclear political action conducted for the institutions or for a macro social class and imposed on society as a whole. A contemporary democratic society is divided into specific social systems which have non-political and nonnormative constitutions and dynamics, a very technical-logical configuration, legitimation and performance (see Habermas, 2012a; 2012b; 2003a). This implies the institutional and political incapability to directly intervene in all (technical-logical) social systems and the institutional political illegitimacy to establish politics itself, political institutions and praxis as the core of social evolution, societal constitution, legitimation and evolution. As Habermas said, politics is one social system among others, one institution of society among others, side by side with other institutions or social systems, not the basis or the center of society - and each social system has its own field and own logic of functioning and programming which is neither political nor normative (see Habermas, 2003b, p. 25, p. 190). Many things are resolved politically, by political institutions and social movements, but other things are a matter of each social system, and they obey to other logics of constitution and legitimation, by the fact that social systems are technical-logical instances which have their own internal and closed logics of functioning and programming that cannot be replaced with political praxis and social normativity. Now, it is here that juridical-political institutions acquire their sense and the definition of their way of acting and functioning; it is finally from here that only the institutions' legal staff acquires legitimacy to act institutionally beyond and overlapped with social movements and citizen initiatives. It is from here that the relationship between juridical-political institutions and civil society, institutions' procedures and legal staff and social movements and citizen initiatives, is understood and defined.

Indeed, in the moment when no social movement can assume a notion of social normativity or perform a political praxis in the name of all society, as a contraposition or even substitution of the juridical-political institutions themselves, it is exactly the institutions which assume, centralize and monopolize the constitution, the legitimation and the public foment of a notion of social normativity, becoming the judge of social evolution and of social movements' political praxis. Such situation puts them as the central basis of societal evolution, because they replace the social classes as the core of society's constitution and dynamics. As a consequence, juridical-political institutions become the intermediate point between social systems and lifeworld or, in Habermas's 
words: juridical-political institutions have a systemic organization, functioning and programming, and at the same time a normative constitution, in the sense that their basis is a notion of normativity and political democracy that defines their constitution, legitimation and evolution over time (see Habermas, 2003a, pp. 61-62, p. 82, p. 190). First of all, therefore, juridical-political institutions are not pure systemic ones, as much as they are not based solely on normativity. On the one hand, as institutions, they have an internal, impartial and neutral proceduralism which is made, justified and streamlined fundamentally from within, by their formal, impartial and neutral procedures and legal staff-they cannot be confused, therefore, pure and simply with the social movements, with the political praxis, by the fact that they are beyond everyday politics and political spontaneity. On the other hand, they act based on normativity and must protect the lifeworld of systemic pathologies. Now, such conditions, programming and functioning of juridical-political institutions are not purely political ones, or purely systemic ones. So what are they? And more importantly, what kind of relationship do the juridical-political institutions establish with social systems and lifeworld? What type of intermediation do they admit and perform?

In the juridical-political procedural paradigm, juridical-political institutions base and intermediate a dialectics between formal spheres and subjects (the very juridical-political institutions, their formal, impartial and neutral procedures, codes and legal staff, as political parties and courts) and informal spheres and subjects (civil society, its social movements and citizen initiatives). Such dialectics is a very direct one: the core of social evolution and of institutional legitimation is constituted and defined by the institutions themselves, because of their impartial, neutral and formal constitution which make them a nonpolitical instance, an impartial structure which is located beyond everyday politics and social struggles. So, due to being constituted and located beyond everyday political struggles and social subjects, juridical-political institutions acquire legitimacy to serve as judges between different and irreconcilable social claims and subjects in the same way that the rule of law, as a formal, impartial and neutral (non-political) institution, becomes the way and the form of democratic political praxis - a very depoliticized way and form of praxis. Here, political obedience to juridical-political proceduralism is the core of the legitimation of both the social-political groups and the social political decisions and claims (see Habermas, 2003a, p. 290). Now, by this apolitical constitution, the juridical-political institutions centralize and monopolize the social power, because they are the effective arbiter and the subject of democratic politics, both institutionally and informally. That is the reason why Rawls and Habermas deny that civil society, its informal spheres and subjects, its political spontaneity have 
the ability to change and to define social evolution and institutional legitimation without the juridical-political institutions; that is the reason, according to Rawls and Habermas, that social movements and citizen initiatives can sensitize and influence the juridical-political institutions' constitution, legitimation and evolution in an indirect way, but never replace them. In the last instance, social movements and citizen initiatives have a secondary role in relation to juridicalpolitical institutions' internal procedural dynamic, codes and legal staff.

There are five fundamental problems which delegitimize the juridicalpolitical procedural paradigm's intention to ground a radical political praxis to a contemporary democratic society: (a) its apolitical starting point that erases social-political-cultural differences and struggles, class division and the status $q u o$ as the basis not only to understanding social evolution, but as a theoreticalpolitical starting point of an emancipatory democratic political praxis; (b) the apolitical understanding of the juridical-political institutions, in that they are conceived of as a set of impartial, neutral, formal, impersonal and procedural rules and practices streamlined by the institutions' legal staff (political parties and courts, for example); (c) the juridical-political institutions' independence regarding the social-political class struggles which superimposes them on social classes or political subjects, as if institutional dynamic, procedures, legal staff and decisions were independent of class hegemony and social struggles; (d) the contraposition - and not the correlation, as intended by Habermas - between formal spheres, procedures and subjects in relation to informal spheres, practices and subjects, which entails juridical-political institutions' centrality in terms of societal constitution, legitimation and evolution and, as a consequence, the inability of civil society to substitute juridical-political institutions, their internal dynamics and legal staff as the effective arena, practice and subjects of social evolution; and finally (e) complex societies' division into different and closed social systems characterized by a technical-logical constitution, legitimation and evolution, which eliminates the democratic political praxis from the social systems' internal dynamics. By the centrality of the juridical-political institutions, their internal proceduralism and legal staff, Rawls and Habermas should recognize that the effective core and subject of social evolution are constituted by the institutions themselves; their theories lead directly or indirectly to what I call strong institutionalism in politics, that is, to the institutional centralization and monopolization of societal constitution, legitimation and evolution, beyond democratic politics, beyond civil society's social movements and citizen initiatives which acquire a secondary political role in relation to institutions. On this point, Rawls's and Habermas's theories are very similar to conservative liberalism, although with many different political consequences. The 
systemic institutional structuration and functioning is always politically central, weakening and at last eliminating political spontaneity from the democratic evolution. Here, institutionalism is the starting and the final point of democracy: it is the arena; it supplies the procedures and codes from which political praxis is streamlined; its legal staff assumes political centrality in terms of institutional constitution and legitimation. Now, this is our great contemporary challenge: to face strong institutionalism in politics, and, as I think, the juridical-political procedural paradigm cannot help us overcome it.

The main objective to be attained, therefore, is to affirm democratic politics beyond and against the apolitical social contract and, as a consequence, beyond and against strong institutionalism. In the first place, what defines institutional constitution, legitimation and evolution are always the social struggles, the social classes, their contraposition and political-cultural hegemony over time. The social contract's apolitical starting point erases such politicity of the institutions, of social life, as it erases the profound class division and opposition which characterize the society's constitution, legitimation and evolution. Here it is not an apolitical starting point which can guarantee the isonomy between citizens and social-political-cultural groups, as well as a fair political result; here, it is not a depoliticized procedure and agreement that can solve class struggles, status quo and institutional dynamics, but exactly the class contraposition, the performance of a permanent direct political praxis which confronts institutions and evidences the political role of both the institutions and the structures of society and of the social subjects which are always and basically political. Likewise, an apolitical starting point and depoliticized social subjects do not allow an educational and emancipatory political praxis that can face political-cultural conservatism, since an apolitical starting point and depoliticized social subjects erases the differences between emancipatory social subjects and conservative social subjects (see Honneth, 2003, 2007). In other words, the apolitical starting point and the depoliticized social subjects render political theory uncritical regarding social evolution, democratic political praxis and emancipation, since it depoliticizes both the social subjects and the social-political conditions, so it is impossible to distinguish emancipatory social subjects and to critically interpret the social-political conditions, which are and always appear as depoliticized in the juridical-political procedural paradigm. However, the problem goes further: the apolitical starting point and the depoliticized social subjects ground a kind of institutionalism that avoids an inclusive social participation at the same time that it limits social movements and citizen initiatives in their ability to confront and replace the institutions themselves, their impartial and neutral procedures and legal staff. An apolitical starting point and the depoliticized social subjects, 
as the basis of the social contract's procedure of juridical-political foundation, leads to strong institutionalism as the core and subject of political society.

In the second place, therefore, facing strong institutionalism is possible through the politicization of the juridical-political institutions, their proceduralism and legal staff, through the refusal of the institutions' neutrality, impartiality and independence regarding class struggles and class hegemony, the social struggles that happen between social subjects in civil society and from it. Institutionalism is not the natural way and result of democracy, as it is not the final end of democratic society. What does that mean? It means that institutions are not an impartial, neutral and formal set of rules, practices and subjects that are independent and superimposed on civil society and its social classes, on the social struggles which happen in civil society and from it, overspreading to all social and institutional spheres. In this sense, institutions are not a pure state without politics, independent and superimposed on political praxis and social struggles, but the result of these social struggles, of class hegemony, as institutional dynamics is dependent on the struggles between social classes. As a consequence, institutionalism is not a kind of intermediation and conciliation between opposed social classes, but a form of weakening of the direct political praxis and social struggles in order to centralize and monopolize the society's constitution, legitimation and evolution within juridical-political institutions, their internal formal proceduralism and legal staff. Here, within institutionalism, the contraposition and the conflict are muted and delegitimized by this impartial, neutral and formal proceduralism resulted from political parties and courts which characterize themselves as impartial, neutral, impersonal and formal regarding political positions and decisions. Now, it is by the scathing and permanent socialpolitical confrontation that strong institutionalism loses its centrality politically and normatively speaking; it is by a radical and permanent political confrontation that strong institutionalism is theoretically and politically deconstructed. It is necessary to break the institutional independence and superposition concerning social movements and citizen initiatives as the condition to the politicization of strong institutionalism and their internal apolitical proceduralism and legal staff. An emancipatory political praxis confronts this independence between formal spheres and subjects versus informal spheres and subjects day after day, which is the basis of both the juridical-political paradigm in particular and the strong institutionalism in general, because such independence delegitimizes a direct democratic political praxis performed by social movements and citizen initiatives against strong institutionalism, legitimizing the centrality of institutionalism as the core of democratic dynamics. Strong institutionalism only survives and legitimizes itself by the separation among institutions, their internal proceduralism 
and legal staff in relation to civil society's informal arenas and social-political subjects. In other words, strong institutionalism only maintains its hegemony and centrality by opposing civil society, social movements and citizen initiatives and by delegitimizing them as a political arena and as political subjects of political praxis, of social transformation.

An alternative theoretical-political position to the juridical-political procedural paradigm refuses its basic principles: an apolitical starting point as the basis of agreement, by the politicization of social struggles as the fundamental core of institutional and societal definition; the independence among institutions, their impartial, neutral and formal proceduralism and legal staff in relation to civil society, its social movements and citizen initiatives; the juridical-political institutions' centralization and monopolization of the legitimacy of social normativity beyond social struggles; the juridical-political institutions' role of intermediation between social systems and lifeworld - since such separation is fictitious and leads to institutional closure and autonomy regarding the spontaneous democratic political praxis; and, finally, the fact that juridicalpolitical institutions, their internal proceduralism and legal staff have the final word in terms of political legitimation of social evolution and of institutional dynamics, only an indirect intervention in the institutions by social movements and citizen initiatives would remain. Institutions are not a set of impartial, neutral and formal rules, practices, procedures and legal staff, because they are rooted in civil society's political arena, defined by social struggles between opposed social groups. The institutional dynamics, constitution and legitimation are determined by class hegemony, by the intensity and range of social struggles. Therefore, it is necessary to radicalize and make pungent these social struggles, this class opposition, the social confrontation of strong institutionalism, of political parties. Only from that theoretical-political starting point - the very politicized role of societal and institutional dynamics, the fact that they are a result of social struggles - it is possible to ground and to streamline a democratic political praxis which can face and win the fight against the most harmful contemporary problem: the profound imbrication among strong institutionalism, political parties and economic oligarchies, which puts down a direct and inclusive political praxis, as the social rooting of the juridical-political institutions and the normative constitution of the capitalist market, erasing the differences between social classes as the basis of institutional and societal dynamics. That imbrication among strong institutionalism, political parties and economic oligarchies legitimizes itself from the affirmation of the centrality of the juridical-political institutions' formal, impartial and neutral proceduralism and legal staff against the criminal, passionate and uncritical core-role of social movements and citizen initiatives, 
which leads to the depoliticization of institutions, of that intrinsic relationship and dependence among institutionalism, political parties and oligarchies, as well as to the depoliticization of social struggles.

Both Rawls and Habermas argue that an effective democratic culture is the political-normative basis of juridical-political proceduralism, of the centrality of the juridical-political institutions, their internal dynamics, rules and legal staff in relation to civil society, its informal arena and social-political subjects (see Habermas, 2003b, p. 25; 2002b, p. 302; Rawls, 2002, p. 50; 2003, § 16, p. 79). Only a mature democratic culture can control and orientate institutionalism. But, as was argued throughout the paper, the separation between juridicalpolitical institutions' formal spheres, impartial and neutral proceduralism and their legal staff, and civil society's informal spheres and subjects leads to institutional closure and autonomy regarding democratic political praxis and, as a consequence, to the depoliticization of the direct political praxis of social movements and citizen initiatives, affirming politics as un apolitical institutional procedure which is impartial, impersonal and neutral concerning social struggles, as if institutions were pure structures, procedures and legal staff of the social constitution, legitimation and evolution, beyond the current political impurity - pure institutions, angelic institutions which are defined and which define from a fair procedure and equal representation, from depoliticized subjects, arenas and procedures, the institutions' and the societal conditions and ways. Democratic culture as the basis of institutionalism only proves that institutionalism is not the society's juridical-political center, but the praxis, the social struggles which generate contrapositions and minimal agreements between opposed social classes. In this sense, the only basis of the juridical-political institutions is the permanent and acute social struggle against conservatism in order to minimize or avoid the correlation among strong institutionalism, political parties and economic oligarchies (see Rancière, 2014). A democratic culture is forged basically by social struggles which lead to the confrontation between social groups, to the problematization of class hegemony and domination. The social struggles, therefore, allow the radical criticism and reformulation of the institutions by the fact that they politicize institutional constitution, dynamics and legitimation, linking institutions with social struggles and class hegemony. In this sense, institutions and societal constitution and dynamics are politicized by social struggles, by the confrontations between opposed social classes. Institutions themselves do nothing; the political praxis resulted from social struggles between social classes defines all societal and institutional dynamics and evolution. 
For many Brazilian intellectuals, social movements and citizens, it is very surprising that the radicalization of the current national political public sphere is not resolved by means of the democratic dialogue and cooperation and institutionalism. It is also surprising that the rule of law and the political institutions, in the moment that they are based on an impartial, neutral and formal proceduralism assumed by juridical-political institutions' legal staff, are used as a form of legitimation of the economic-political corruption, as a political instrument for the status quo and class division-political parties and economic oligarchies, very imbricated, use institutional proceduralism against democracy, as a form of delegitimation of an inclusive and radical political praxis which problematizes strong institutionalism, the association among strong institutionalism, political parties and economic oligarchies as the fundamental problem of democratic societies in general and of Brazilian democracy in particular. In other words, by means of a pure, formal, neutral and impartial juridical-political proceduralism, the Brazilian right launched a coup d'État, proving that strong institutionalism cannot be understood separated from and superimposed on social struggles between opposed social classes, separated of class hegemony. Therefore, the social struggles between opposed social classes acquire theoretical-political centrality as the basic core and role to the politicization of institutions, societal constitution, legitimation and dynamics in a time in which the growth of cultural-political conservatism delegitimizes political democracy and social inclusion by the separation between institutions and civil society, formal spheres, procedures and subjects in relation to informal spheres and subjects. In other words, the hegemonic cultural-political conservatism emphasizes strong institutionalism as the fundamental basis of a democratic society, of the legitimation of social systems and juridical-political institutions. Here, an apolitical juridical-political procedural paradigm not only cannot legitimize a direct political praxis against strong institutionalism, but indeed legitimizes such a strong institutionalism, its self-referentiality, independence and superimposition regarding civil society, depoliticizing it and denying it as a very political arena and subject.

\section{Bibliography}

FORST, R. "Contextos da justiça: filosofia política para além de liberalismo e comunitarismo". São Paulo: Boitempo, 2010.

HABERMAS, J. "Teoria da ação comunicativa (Vol. I): racionalidade da ação e racionalização social”. São Paulo: Martins Fontes, 2012a.

. "Teoria da ação comunicativa (Vol. II): sobre a crítica da razão funcionalista". São Paulo: Martins Fontes, 2012b. 
. "Direito e democracia: entre facticidade e validade (Vol. I)". Rio de Janeiro: Tempo Brasileiro, 2003a.

. "Direito e democracia: entre facticidade e validade (Vol. II)". Rio de Janeiro:

Tempo Brasileiro, 2003b.

. "O Discurso filosófico da modernidade: doze lições". São Paulo: Martins Fontes, 2002a.

. "A inclusão do outro: estudos de teoria política". São Paulo: Loyola, 2002b.

. "Ensayos políticos". Barcelona: Ediciones Península, 1997.

. "Pensamento pós-metafísico: estudos filosóficos". Rio de Janeiro: Tempo

Brasileiro, 1990.

1989.

. "Consciência moral e agir comunicativo". Rio de Janeiro: Tempo Brasileiro,

HAYEK, F. A. von. "O caminho de servidão". Rio de Janeiro: Instituto Liberal, 1987. . "Arrogância fatal: os erros do socialismo". Porto Alegre: Ortiz Editores, 1995. HONNETH, A. "Luta por reconhecimento: a gramática moral dos conflitos sociais". São Paulo: Editora 34, 2003.

2007. . "Reificación: un estudio en la teoría del reconocimiento". Buenos Aires: Katz,

NOZICK, R. “Anarquia, Estado e utopia”. Rio de Janeiro: Jorge Zahar, 1991.

RANCIÈRE, J. "O ódio à democracia”. São Paulo: Boitempo, 2014.

RAWLS, J. "Uma teoria da justiça”. São Paulo: Martins Fontes, 2000a. . "Justiça e democracia". São Paulo: Martins Fontes, 2000 b. . "O liberalismo político". São Paulo: Ática, 2002. . "Justiça como equidade: uma reformulação". São Paulo: Martins Fontes, 2003. 